\title{
Профілактика специфічних ускладнень ендовенозної лазерної коагуляції
}

\author{
С. М. Василюк ${ }^{1}$, Б. В. Криса ${ }^{1}$, В. В. Холін ${ }^{2}$
}

${ }^{1}$ Івано-Франківський національний медичний університет,

${ }^{2}$ Приватне підприемство «Фотоніка Плюс», м. Черкаси

\section{Prophylaxis of specific morbidity of endovenous laser coagulation}

\author{
S. M. Vasyliuk ${ }^{1}$, B. V. Krysa ${ }^{1}$, V. V. Kholin ${ }^{2}$ \\ ${ }^{1}$ Ivano-Frankivsk National Medical University, \\ ${ }^{2}$ Private Enterprise «Fotonika Plus», Cherkasy
}

Реферат

Мета. Розробити методику профілактики специфічних ускладнень ендовенозної лазерної коагуляції.

Матеріали і методи. Запропоновано спосіб профілактики розвитку специфічних ускладнень ендовенозної лазерної коагуляції шляхом активного видалення продуктів коагуляції з просвіту вени. Проведено спостереження за двома групами хворих, яким виконували лазерне втручання класичним методом (1-ша група) та з використанням розробленої методики (2-га група).

Результати. Запропоновані спосіб і пристрій для вакуумної евакуації продуктів коагуляції із зони операції унеможливлюють потрапляння їх у венозну систему і запобігають розвитку ранніх специфічних післяопераційних ускладнень («металевого» присмаку в роті, головного болю, запаморочення, загального нездужання, «важкості» дихання), що покращує перебіг післяопераційного періоду.

Висновки. Вакуумна евакуація продуктів коагуляції з просвіту вени запобігає їх потраплянню у загальну венозну систему, мінімізує частоту розвитку специфічних ускладнень і покращує перебіг раннього післяопераційного періоду. Використання методики профілактики ускладнень ендовенозної лазерної коагуляції в лікуванні варикозної хвороби і пристрою для його реалізації не ускладнює виконання операції і не збільшує ії вартість.

Ключові слова: варикозна хвороба; ендовенозна лазерна коагуляція; профілактика ускладнень.

Abstract

Objective. To elaborate a procedure for prevention of specific morbidity of endovenous laser coagulation.

Materials and methods. A procedure for prophylaxis of specific morbidity of endovenous laser coagulation, using active elimination of the coagulation products from venous lumen was proposed. The investigation was performed for two groups of patients, to whom the laser intervention was done in accordance to classic method (1-st Group) and using a procedure elaborated (2-nd Group).

Results. The method and the apparatus proposed for the vacuum evacuation of the coagulation products from the operation zone makes impossible their entry into venous system and prevents the development of early specific postoperative complications («metallic» taste in the mouth, a headache, dizziness, general ailment, a respiration «difficulty»), what improves the postoperative period course.

Conclusion. Vacuum evacuation of the coagulation products from the vein lumen prevents their entry into common venous system, minimizes the rate of the specific complications development and improves the early postoperative period course. Prophylaxis of specific morbidity of endovenous laser coagulation in the treatment of varicose disease as well as apparatus for its realization do not complicate the operation performance nor enhances its cost.

Keywords: varicose disease; endovenous laser coagulation; prophylaxis of morbidity.

Ендовенозна лазерна коагуляція (ЕВЛК) $є$ пріоритетним напрямком лікування варикозної хвороби (BX) нижніх кінцівок (НК). Завдяки малій травматичності втручання, доброму естетичному ефекту та стислим строкам реабілітації ЕВЛК стала альтернативою класичним оперативним втручанням і їі навіть почали сприймати як досконалий метод лікування ВХ. Метод ЕВЛК полягає у фототермічному ушкодженні стінки судини лазерною енергією, яка викликає вапоризацію (закипання крові і утворення бульбашок пари з температурю $100^{\circ} \mathrm{C}$ ), фотокоагуляцію та карбонізацію крові і стінки судини. Наслідком термічної дії лазера є первинне «склеювання» стінок судини під впливом еластичної компресії кінцівки після втручання 3 наступним фіброзним ії переродженням [1].
Разом з тим лазерна фотокоагуляція спричиняє ряд специфічних ускладнень, зокрема, сегментарний тромбофлебіт, паравазальні опіки, які іноді переходять на шкіру, екхімози, тривалу гіперпігментацію шкіри над зоною коагуляції, парестезії та інші неврологічні порушення, загальну гіпертермічну реакцію, а також реканалізацію вени у віддаленому періоді після втручання.

Окремо виділяють ускладнення, причиною яких є сама лазерна коагуляція. Зокрема, ультразвуковий контроль під час коагуляції в робочій зоні світловода візуалізує множинні бульбашки газу, які переміщуються у проксимальному напрямку і потрапляють через сафено-феморальне співустя в глибокі вени. Далі продукти лазерної коагуляції потрапляють з плином крові в порожнисту вену, ма- 
ле коло кровообігу та судини головного мозку [2]. У ранньому післяопераційному періоді 83\% пацієнтів відмічають неприємний «металевий» присмак у роті, головний біль, запаморочення, загальне нездужання, нудоту, «важкість» при диханні. Ці симптоми утримуються від $2-3$ до 6 - 7 днів після операції і створюють дискомфорт для пацієнтів у ранньому післяопераційному періоді.

Ультразвукове дослідження виявляє пухирці газу, які утворюються на торці світловода і рухаються в проксимальному напрямку. Видимі на моніторі бульбашки газу можна спостерігати у просвіті вени протягом 5 - 7 хв. Таким чином, проявом феномену вапоризації є специфічні для нього клінічні та сонографічні симптоми [3].

Для профілактики ускладнень ряд авторів доповнюють процедуру ЕВЛК кросектомією $[4,5]$. Проте кросектомія лише зменшує, але не усуває повністю ризик розвитку специфічних ускладнень лазерної деструкції варикозно розширеної вени через те, що бульбашки газу разом з продуктами лазерної фотокоагуляції і карбонізації можуть потрапляти в глибоку венозну систему через перфорантні вени на стегні і гомілці, по яких в нормі кров перетікає із підшкірних вен у глибокі.

Варто окремо зазначити, що ряд авторів, які виконують ЕВЛК в амбулаторних умовах, не доповнюють ії кросектомією, щоб не ускладнювати операції і не подовжувати їі тривалості $[6,7]$.

Мета дослідження: розробка методики попередження виникнення специфічних ускладнень ЕВЛК в ранньому післяопераційному періоді і порівняння клінічних характеристик стану пацієнтів, яким було виконано класичне втручання, і у яких було використано запропоновану методику.

\section{Матеріали і методи дослідження}

Протягом 2016 - 2018 рр. нами прооперовано 26 пацієнтів (I-ша група) з ВХНК із використанням методики ЕВЛК та активної евакуації продуктів коагуляції з операційної зони для попередження розвитку специфічних ускладнень ЕВЛК. Оперовані раніше 25 пацієнтів, у яких ЕВЛК виконували без видалення продуктів коагуляції, склали 2-гу групу (контрольну).

ЕВЛК виконували за стандартним протоколом. Антеградно або ретроградно вводили світловод у просвіт вени з наступною його повільною екстракцією та одночасною коагуляцією вени. В процесі екстракції та лазерної коагуляції варикозно розширеної вени здійснюва-

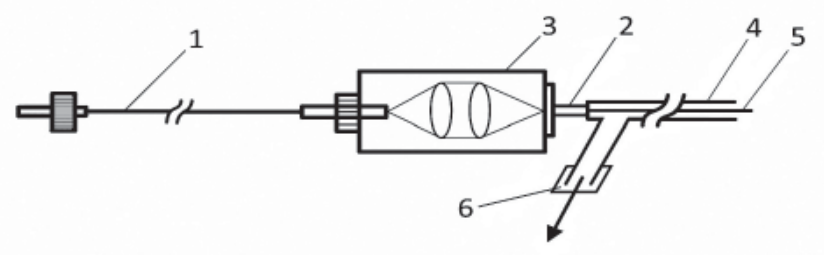

Пристрій для ендовенозної лазерноїхірургіӥ:

1 - апаратна частина світловода; 2 - операціина частина світловода; 3 - оптико-механічний з'єднувач двох світловодів; 4 - еластичний катетер із співвісно розміменим всередині світловодом; 5 - робочий кінець світловода; 6 - трубчате відгалуження еластичного катетера 4 з канюлею для підключення до відсмоктувача. ли активне видалення (відсмоктування) продуктів вапоризації, фотокоагуляції і карбонізації із зони лазерної коагуляції через дренажну систему, з'єднану з джерелом вакууму, наприклад, хірургічним вакуумним відсмоктувачем. За допомогою відсмоктувача евакуювали продукти коагуляції протягом усього часу роботи хірургічного лазера.

Для забезпечення такого методу оперативного втручання ми запропонували конструктивне виконання пристрою для ЕВЛК (див. рисунок), який складається з двох елементів: нестерильної апаратної частини гнучкого світловода 3 оптико-механічним перехідником, що приймає і фокусує лазерне випромінювання. До оптико-механічного перехідника під'єднували стерильний операційний гнучкий світловод, який передавав лазерну енергію до зони коагуляції.

Операційну частину світловода нижче оптико-механічного з'єднання вводили в стерильний порожнистий ангіографічний катетер, внутрішній діаметр якого є більшим за зовнішній діаметр світловода, що утворює по всій довжині світловода вільний простір між світловодом і катетером, причому робочий кінець світловода виступає за кінець порожнистого катетера, а останній біля з'єднуючої частини має трубчате відгалуження з канюлею, яку під'єднували під час операції до хірургічного вакуумного апарата і відсмоктували продукти лазерної коагуляції $[8,9]$.

Таке конструктивне виконання пристрою для ЕВЛК, у якому по всій довжині світловода є вільний простір між світловодом і катетером, забезпечує можливість під'єднання його під час операції через канюлю до хірургічного вакуумного відсмоктувача і евакуацію продуктів лазерної коагуляції, що мінімізує або унеможливлює потрапляння їх у кровоносне русло пацієнта і попереджує розвиток специфічних ускладнень ендовенозного лазерного втручання.

\section{Результати}

ЕВЛК з приводу ВХНК виконували згідно зі стандартним протоколом операції, за винятком того, що перед етапом виконання коагуляції канюлю трубчатого відгалуження еластичного катетера з'єднували з вакуумним відсмоктувачем і видаляли продукти коагуляції протягом усього часу роботи хірургічного лазера.

Більшість пацієнток звернулись зі скаргами на наявність варикозно розширених підшкірних вен НК, набряк ніг у другій половині дня та періодичні нічні судоми. Часто початок і прогресування захворювання пов'язували з вагітностями та пологами.

Під час клінічного обстеження виявляли варикозне розширення в системі підшкірних вен та їх гілок на НК. За даними ультразвукового ангіосканування у 90\% хворих було виявлено неспроможність устіальних клапанів та клапанів підшкірних вен, вертикальний та горизонтальний рефлюкси.

Після обробки операційного поля під тумесцентною анестезією розчином Кляйна із мінідоступів у ділянках внутрішніх кісточок гомілок у просвіти варикозно розширених вен вводили стерильні еластичні ангіографічні катетери із встановленими в них світловодами та проводили їх до сафено-феморального співустя. Якщо діаметр вени у сафено-феморальному співусті перевищував 10-12 мм, виконували кросектомію. Для прискорення пошуку співустя великої підшкірної вени вмикали пі- 
лотний червоний промінь. Апаратну частину світловодів з'єднували з оптико-механічним вузлом, а канюлю трубчатого відгалуження еластичного катетера - 3 хірургічним вакуумним відсмоктувачем.

ЕВЛК виконували коагулятором «Ліка-хірург» 3 довжиною хвилі 1470 нм у постійному режимі випромінювання потужністю 9 Вт. Перед початком роботи одночасно вмикали хірургічний вакуумний відсмоктувач і режим лазерної коагуляції та поступово виводили катетер з просвіту вени зі швидкістю 1,5 - 2 мм/с. Коли робочий кінець світловода знаходився над недостатніми перфорантними венами, його евакуацію затримували на 1 - 2 с.

Загальна доза лазерного випромінювання під час втручання на одній кінцівці становила (1900 \pm 80) Дж, на двох - (3800 土90) Дж. Після виведення катетера з світловодом із коагульованої вени по ходу ії накладали марлевий асептичний валик, а на мінідоступи - косметичні шви. На оперовані кінцівки накладали компресійні еластичні бинти.

Після втручання в день його виконання і на наступний день опитували хворих про наявність чи відсутність у них специфічних скарг. Частота виникнення специфічних ускладнень ЕВЛК у ранньому післяопераційному періоді у хворих 1-ї групи, яким під час втручання видаляли продукти лазерної коагуляції, та 2-ї групи (контрольної), яким їх не видаляли, подана в таблиці.

\section{Обговорення}

Отримані нами попередні результати корелюють з даними клінічних спостережень [2, 3], у яких показано, що після виконання кросектомії значно зменшуються інтенсивність і частота виникнення післяопераційних специфічних симптомів, зокрема, головного болю, «металевого» присмаку у роті, нудоти, «важкості» дихання тощо.

Спостерігаючи за пацієнтами в ранньому післяопераційному періоді після евакуації продуктів лазерної фотокоагуляції із зони операції під час виконання ЕВЛК, ми зафіксували незначний показник розвитку специфічних симптомів потрапляння продуктів лазерної вапоризації та коагуляції у венозне русло у порівнянні з контрольною групою. Варто відмітити, що використання запропонованого способу профілактики ускладнень ЕВЛК під час лікування ВХ і пристрою для його реалізації не ускладнюе виконання операції і не збільшуе ії вартості.

Переваги запропонованого способу профілактики ускладнень ЕВЛК і пристрою для його реалізації полягають у тому, що вакуумна евакуація продуктів лазерної фотокоагуляції з операційної зони мінімізує можливість їх потрапляння у венозну систему і частоту розвитку специфічних для ендовенозної лазерної хірургії ускладнень, що покращує перебіг раннього післяопераційного періоду і створює комфортні умови для пацієнтів.

\section{Висновки}

1. Вакуумна евакуація продуктів лазерної коагуляції попереджує можливість їх попадання під час операції в загальну венозну систему.

2. Видалення продуктів фотокоагуляції з просвіту вени мінімізує частоту розвитку специфічних ускладнень і покращує перебіг раннього післяопераційного періоду.

\begin{tabular}{|c|c|c|c|c|}
\hline \multicolumn{5}{|c|}{$\begin{array}{l}\text { Частота виникнення специфічних ускладнень ЕВЛК } \\
\text { у групах хворих }\end{array}$} \\
\hline \multirow{3}{*}{$\begin{array}{c}\text { Специфічні для ЕВлК } \\
\text { післяопераційні ускладнення }\end{array}$} & \multicolumn{4}{|c|}{ Група хворих } \\
\hline & \multicolumn{2}{|c|}{$\begin{array}{c}\text { 1-ша } \\
(n=26)\end{array}$} & \multicolumn{2}{|c|}{$\begin{array}{c}2-г a \\
(n=25)\end{array}$} \\
\hline & абс. & $\%$ & абс. & $\%$ \\
\hline «Металевий» присмак у роті & 3 & 11,5 & 21 & 84 \\
\hline «Важкість» дихання & 1 & 3,8 & 18 & 72 \\
\hline Головний біль & 2 & 7,7 & 17 & 68 \\
\hline Запаморочення & 1 & 3,8 & 13 & 52 \\
\hline Загальне нездужання & 2 & 7,7 & 9 & 36 \\
\hline Нудота & 1 & 3,8 & 7 & 28 \\
\hline
\end{tabular}

3. Використання запропонованого способу профілактики ускладнень ЕВЛК під час лікування ВХ і пристрою для його реалізації не ускладнює виконання операції і не збільшуе ії вартості.

\section{Підтвердження \\ Фінансування}

Ініціативно-пошукова робора. Фінансування публікації власним коштом.

\section{Внесок авторів}

Всі автори внесли однаковий внесок у цю роботу.

\section{Конфлікт інтересів}

Автори, які взяли участь в цьому дослідженні, декларують відсутність конфлікту інтересів щодо цього рукопису.

\section{Згода на публікацію}

Всі автори дали згоду на публікацію цього рукопису.

\section{References}

1. Biemans AA, Kockaert M, Akkersdijk GP, van den Bos RR, de Maeseneer MG, Cuypers $P$, et al. Comparing endovenous laser ablation, foam sclerotherapy, and conventional surgery for great saphenous varicose veins. J Vasc Surg. 2013;58(3):727-34. doi: 10.1016/j.jvs.2012.12.074.

2. Svystun OH. Pisliaoperatsiini uskladnennia endovenoznoi lazernoi koahuliatsii varykoznykh ven nyzhnikh kintsivok. Medsestrynstvo. 2013;1:3740. doi: 10.11603/2411-1597.2013.1.5301. [In Ukrainian].

3. Hoshchynskyi VB, Havryliuk MV, Piatnychko OZ, Stasiv MIa. Pro spetsyfichni uskladnennia endovenoznoi lazernoi koahuliatsii varykoznykh ven nyzhnikh kintsivok. Shpytalna khirurhiia. 2012;(3):108-10. doi: 10.11603/1681-2778.2013.3. [In Ukrainian].

4. Hoshchynskyi VB, Havryliuk MV, Kohut VH. Pro deiaki tekhnichni y taktychni aspekty vykonannia endovenoznoi lazernoi koahuliatsii. Shpytalna khirurhiia. 2013;(1):89-91. doi: 10.11603/1681-2778.2013.1.1633. [In Ukrainian].

5. Flessenkämper, Hartmann M, Hartmann K, Stenger D, Roll S. Endovenous laser ablation with and without high ligation compared to high ligation and stripping for treatment of great saphenous varicose veins: Results of a multicentre randomised controlled trial with up to 6 years follow-up I. Phlebology. 2016;31(1):23-33. doi: 10.1258/phleb.2011.011147

6. Kuz'menko OV, Mihajlichenko VJu, Mishalov VG, Mirgorodskij DS. Innovacionnye metody hirurgicheskogo lechenija varikoznoj bolezni nizhnih konechnostej: diskussionnye voprosy. Khirurhiia Ukrainy. 2015;(1):112-9. [In Russian].

7. Palamarchuk VI, Khodos VA, Cherniak VA, Krysa VM. Alhorytm suchasnykh likuvalnykh tekhnolohii v ambulatornii khirurhii varykoznoi khvoroby nyzhnikh kintsivok. Klinichna khirurhiia. 2013;(2):36-40. PMID:23705479. [In Ukrainian].

8. Krysa BV, vynakhidnyk; Krysa BV, patentovlasnyk. Sposib profilaktyky uskladnen endovenoznoi lazernoikoahuliatsii pry likuvanni varykoznoi khvoroby. Patent Ukrainy No 111073. 2016 zhov 25.

9. Krysa VM, Krysa BV, Kholin VV, vynakhidnyky; pryvatne male vyrobnyche pidpryiemstvo «Fotonika plius», patentovlasnyk. Prystrii dlia endovaskuliarnoi khirurhii. Patent Ukrainy No 119240. 2017 ver 25.

Отримана 25.10.2018 